\title{
An overview of ESP and EAP in language pedagogy
}

\section{Ourania Papadima}

Mediterranean College, Athens, Greece

\begin{abstract}
The English language is widely used in educational institutes around the world, and especially in Higher Education. This has led to the development of English for Academic Purposes (EAP), a new branch within the field of English for Specific Purposes (ESP). This chapter is aimed at providing a conceptual framework for ESP and EAP. To this end, the chapter will focus on the diachronic development of ESP, the differences between ESP, EAP and EOP (English for Occupational Purposes), and the distinction of EAP in EGAP (English for General Academic Purposes) and ESAP (English for Specific Academic Purposes). Relevant key concepts in English language pedagogy, such as curriculum and syllabus design, as well as current issues in the field of EAP research, are also examined.
\end{abstract}

Key words: English for Specific Purposes (ESP), English for Academic Purposes (EAP), curriculum, syllabus, course design

\section{Introduction}

This chapter aims to shed light on the typology of English for Specific Purposes (ESP) and English for Academic Purposes (EAP) within English language pedagogy. The above two concepts are now critical in English language research and teaching, and especially in course design. Given the prominence of specificity in terms of learner needs, content and methodology in ESP (as will be discussed below), it is essential to gain an understanding of what constitutes the curriculum and the syllabus and how they are pertinent to ESP/EAP. The chapter will seek to provide a concise overview of the theoretical background and development of ESP and EAP. To that end, key concepts will be discussed; particularly, the underpinning principles of Curriculum Development, Course Design, Needs Analysis and English for Specific Purposes. 


\section{Curriculum}

What follows is an attempt to offer an overview of Curriculum development in language teaching or Curriculum studies, which is closely related to Syllabus design. The relevant literature abounds with definitions of the above two concepts (Brown, 1995; Crombie, 1988; Clark, 1987; Graves, 1996; Lee, 1980; Nunan, 1988; White, 1988); however, the present chapter will only provide a limited number of definitions of Curriculum and Syllabus for clarification purposes.

Historically, curriculum development can be said to have begun in the 1960s, while issues related to syllabus design came to light earlier along with changes in teaching methodology (Richards, 2001). According to Thornton (2014), "a curriculum is a program consisting of a series of learning activities intended to realise some set of educational objectives. The mission of a school or other educational agency is understood to be the delivery of a curriculum to some group of students or other learners". Richards (2001) specifies that the main aim of curriculum development is threefold: to establish the set of knowledge, skills and principles that learners are taught in schools, to identify the experiences that will lead to achieving the learning goals, as well as to determine other aspects such as measurement and evaluation of teaching and learning. Thus, the curriculum is designed to delineate the learning aims and objectives, as well as the ways the above can be achieved, in a given educational setting, and as such it is of highly practical value.

In addition, it is argued (Apple, 1990) that the curriculum also has social, economic and ideological dimensions and does not stand isolated in an educational setting. Therefore, although the curriculum seems to serve only educational purposes it is not limited to an educational setting. Instead, it can be affected by the context in which it has been created and may be intended to influence aspects of life other than education. In line with Apple's argument, several scholars (Dewey, 1938; Sambell \& McDowell, 1998; Semper \& Blasco, 2018) have claimed that in addition to the explicit curriculum, which is usually known to students and teachers, there is also the hidden curriculum, or in more simple terms that "schools teach more than they claim to teach" (Vallance, 1974, p. 5). In the definition Thornton (2014) provides, he maintains that the "hidden curriculum is implemented via routines and attitudes instilled through students' experiences with the explicit curriculum and its milieu; these experiences may be consonant or dissonant with the explicit curriculum". Thornton adds that the hidden curriculum can be more influential than the explicit one, and therefore failing to recognise and acknowledge it can impair one's understanding of the real nature of any given curriculum. Research also acknowledges the importance of the hidden curriculum 
in Higher Education (Margolis, 2001). Endorsing the above, Semper and Blasco (2018) propose that teachers in Higher Education should pay attention to the hidden curriculum, and eventually eliminate it by viewing their teacher roles as a more personal issue.

\section{Syllabus}

Despite the link between the curriculum and the syllabus, or even the confusion often accompanying them, a distinctive line can be drawn between the two. The former is related to aims and objectives, methodology and materials, whereas the latter can be defined as "the way in which that content is organized and broken down into a set of teachable and learnable units, and will include consideration of pacing, sequencing and grading of items, methods of presentation and practice" (McDonough, Shaw \& Masuhara, 2013), or as White (1988, p. 4) puts it in his seminal work the ELT Curriculum "syllabus refers to the content or subject matter of an individual subject whereas curriculum refers to the totality of content to be taught and aims to be realised with one school or education system". Finally, it has also been suggested that the syllabus is a declaration of the teacher's beliefs regarding teaching, learning and language (Hyland, 2006); thus, it can also constitute the means through which teachers can make their methodology and approach known to the learners.

As far as classification is concerned, White (1988) discusses three types of curriculum:

A: The Rational Planning model; starting with a clear specification of aims and objectives and moving on to content, learning experiences and evaluation

B: The Process approach to curriculum design; whereby teachers start with the context, then define the learning situation and the aims and finally implement evaluation

C: The situational model; based on analysis of cultural factors and starting with an analysis of the educational setting itself.

A distinction is also drawn between the following two types of syllabus; a) Type $\mathrm{A}$, which presupposes emphasis on the subject, assessment through achievement, and objectives defined in advance by the teacher and b) Type B, requiring emphasis on the process, negotiation between teachers and students and commonly defined content and objectives (White, 1988).

A further classification of approaches to syllabus design is provided by Krahnke (1987). He discusses six types of language teaching syllabus, namely 
the Structural, Notional/ Functional, Situational, Skills-based, Task-based, and Content-based syllabi, putting them on a continuum, whereby the first one places more emphasis on language form, while the last one on language content. In reviewing relevant literature (Nunan, 1993; Wilkins, 1976; Widdowson, 1990), two more approaches to syllabus design emerge, namely the synthetic and the analytic syllabus. The former calls for a systematic step-by-step instruction, where the language structures are taught separately and in a linear and gradual fashion, while the latter is rather more holistic and views linguistic competence as a means to perform communicative tasks. With regard to EAP, Bruce (2005) proposes a cognitive genre approach to syllabus design, arguing that it is optimal for a General EAP course. Finally, in English for Specific Purposes: A learningCentered Approach Hutchinson and Waters (1987) argue not only for the importance of a syllabus, but also for the existence of several stages to it: the evaluation, organizational, materials, teacher, classroom, and learner syllabus.

\section{ESP and EAP}

\subsection{ESP}

English for Specific Purposes (ESP), as a branch of English Language Teaching, emerged in the 1960s and has since given rise to extensive research and definitions. The roots of ESP, though, can be traced back to the aftermath of the Second World War. In fact, Hutchinson and Waters (1987) have suggested three reasons that gave rise to the ESP phenomenon. First of all, vast scientific and technological advances created a globalised world and, thus, the need for an international language. That role was assumed by English, mainly for reasons related to power and this led to the need to learn English for specific purposes, such as working in trade. Secondly, the aim of Linguistics changed from describing the language to analysing the characteristics of English used in certain fields of work or study. And, finally, advances in the field of Educational Psychology shifted the focus from the teacher to the learner, thereby creating the need for courses that would suit the learners' needs and increase their motivation.

The above gave rise to an ESP movement that is not confined to English speaking countries. ESP courses are delivered in places outside the inner circle countries (Kachru, 1985) where English is the first language. In fact, there are now ESP associations, journals and numerous publications worldwide but also seemingly a lingering question as to what exactly constitutes ESP and how it can 
be implemented in the classroom. Finally, it is noteworthy that ESP teachers seem to often utilise research, perhaps more frequently than General EFL practitioners, since in order to cater for specific learner needs, they are often required to act as course designers, too.

To return to the previous question of what constitutes ESP, the following definitions can be examined. Paltridge and Starfield (2013) have defined ESP as "the teaching and learning of English as a second or foreign language where the goal of the learners is to use English in a particular domain". Johnson and Johnson (1998, p. 105) have described it as a "broad and diverse field of English language teaching" that refers to "language programmes designed for groups or individuals who are learning with an identifiable purpose and clearly specified needs", while the ESP student has been described as a learner studying English "in order to carry out a particular role, such as that of foreign student in an Englishmedium university, flight attendant, mechanic, or doctor" (Richards, 2001, p. 28). Hutchinson and Waters (1987, p. 19), on the other hand, have concluded that ESP should not be deemed a "language product but an approach to language teaching which is directed by specific and apparent reasons for learning". Given the number of definitions that have been offered (Hutchinson and Waters, 1987; DudleyEvans and St John, 1998; Strevens, 1988; Swales, 1990), it is probably safe to draw the conclusion that defining ESP is a rather challenging task. However, it is worth noting the similarities that permeate most definitions: ESP is designed to meet specific learner needs in particular situations. More specifically, a number of characteristics of ESP, falling in two categories, have been identified in DudleyEvans and St Johns's work, drawing on Streven's (1988) list of characteristics:

Absolute characteristics of ESP

- It is designed to meet specific learner needs

- It uses relevant methodology and tasks depending on the discipline; ESP methodology is centered on the language, skills, discourse and genres appropriate to these activities.

Variable characteristics of ESP

- It may or not be related to or designed for specific subject fields

- It may use a different methodology from that of General English

- It is probably designed for adult learners, either at HE or in a professional setting

- It is usually designed for intermediate or advanced students.

(Dudley-Evans and St John, 1998). 


\subsection{ESP branches}

Despite the shared characteristics of ESP courses, ESP can be divided in two categories: English for Occupational Purposes (EOP) and English for Academic Purposes (EAP) (Woodrow, 2018), depending on the learners' needs and specificity of content. The following figure illustrates EOP and its subdivisions.

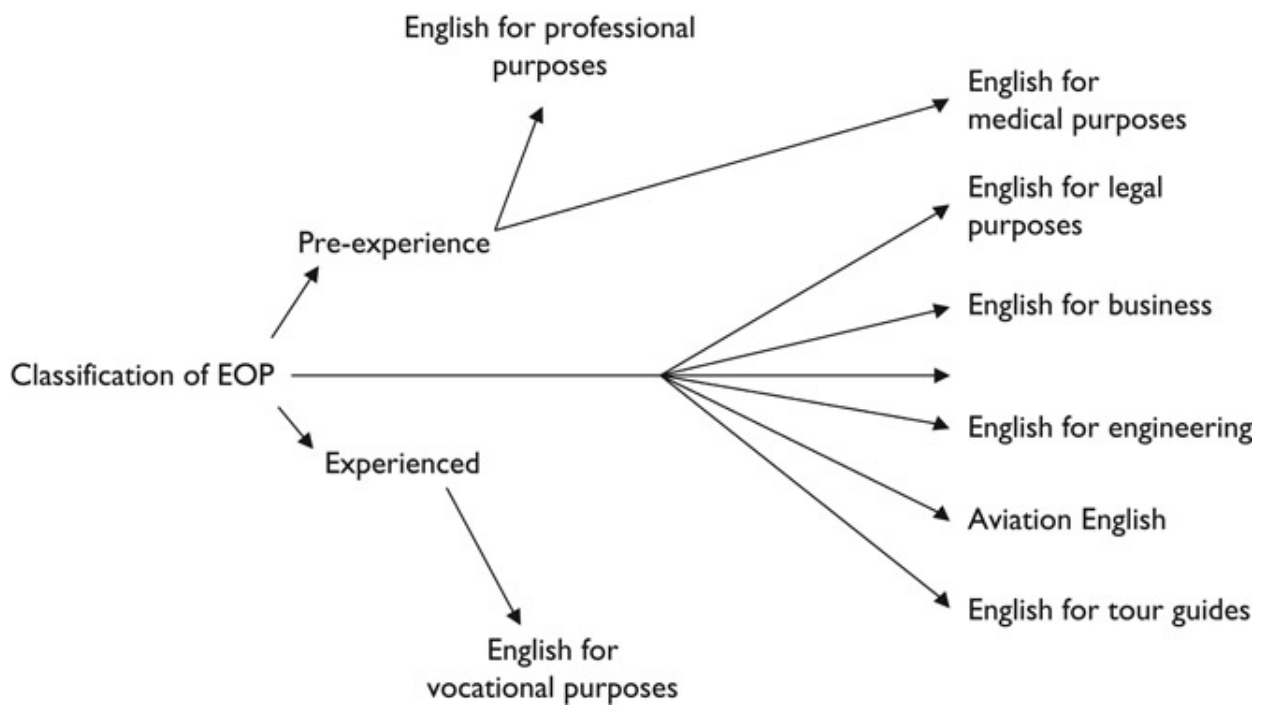

Fig. 1. Classification of EOP (Woodrow, 2018)

The second category of ESP, namely EAP, has been described as the teaching of English with a view to enabling learners to pursue studies or research in English (Flowerdew and Peacock, 2001a), while Hyland and Hamp-Lyons (2002) have added the element of culture, arguing that in addition to literacy skills, EAP courses should teach students the communication skills that are required in various academic and cultural environments.

EAP can in turn be divided into a number of branches. An EAP course may focus on English for General Academic Purposes (EGAP) or on English for Specific Academic Purposes (ESAP). In EGAP students may be working in different fields of study, but require Academic English, whereas an ESAP course is attended by learners from the same discipline, such as Psychology or Business, and the materials are directly related to the learners' field of study. Moreover, there can be further classifications depending on the setting and the time the students are taking the course. For example, an EGAP Pre-sessional course is designed for students of various backgrounds who are studying Academic English before 
embarking on their studies, whereas students studying ESAP along with their main studies could be on an In-sessional course. The following diagram clearly illustrates the EAP branches, drawing on Woodrow's classification (2018):

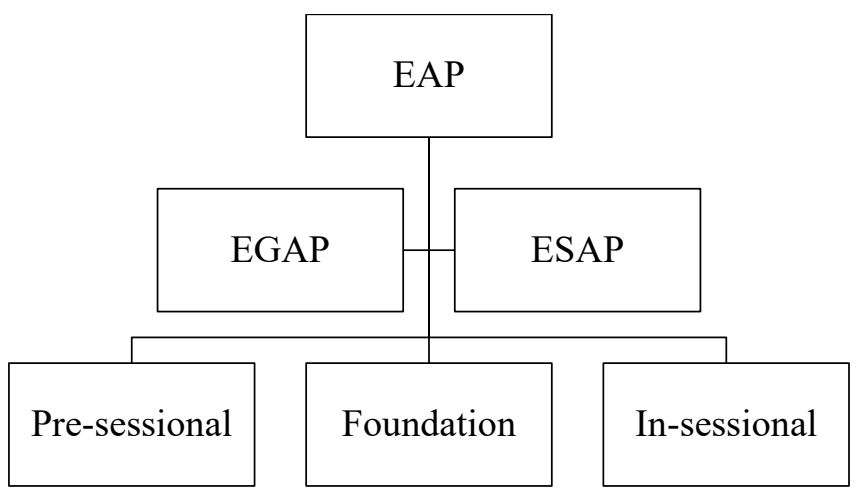

Fig. 2. Branches of EAP (Woodrow 2018)

\subsection{EAP issues}

Having made the distinction between EGAP and ESAP, researchers and teachers identify the key role of specificity in EAP, that is, the difference between the two branches. Taking an EGAP approach, Dudley and St John (1998, p. 41) described what they saw as key activities in EAP (e.g., Listening to lectures, participating in seminar discussions, reading academic articles and producing academic texts, such as essays). However, other researchers and teachers prefer to follow an ESAP approach and argue that there is an adequate number of differences between the two branches, and therefore courses that cover different and discipline-specific needs are required. Summarising the main reasons for an EGAP approach, Hyland (2006, pp. 10-11) notes that there are academic skills shared interdisciplinarily and that EAP courses should focus on language useful across subject fields. On the other hand, while discussing reasons for adopting an ESAP approach he raises the issue of what constitutes generic language and skills and expresses reservations over the concept of language common across disciplines. The conclusion that is finally drawn is that despite the shared feature of formality, it is not easy to delineate common language characteristics across disciplines, and that teachers and learners should be active participants and negotiators in the learning process (Hyland, 2006, pp. 11-14). 


\section{Course design in EAP}

A further concept worth clarifying is that of Course design. While the Curriculum "includes the philosophy, purposes, design and implementation of a whole programme" (Nunez y Bodegas, 2007), a course is "an integrated series of teaching learning experiences, whose ultimate aim is to lead the learners to a particular state of knowledge" (Hutchinson and Waters, 1987, p. 65). The central role of course design in ESP, which encompasses EAP, as has been discussed, has frequently been highlighted in relevant literature (Basturkmen, 2010; Blaj-Ward, 2014; Flowerdew and Peacock, 2001b; Hutchinson and Waters, 1987). In the case of ESP the most common approach to course design is the language-centred one, for reasons that pertain to the significance of Needs analysis in ESP; that is, the language-centred approach is common in the field, as it utilises the relation between learners' needs and course content. Nevertheless, in their discussion on approaches to course design in ESP Hutchinson and Waters (1987) suggest that a negotiated, dynamic, non-linear approach, called learning-centred approach (putting the learning process at the forefront, as opposed to a learner-centred one) would be optimal in the field of ESP. They also argue that such an approach takes the learner into account throughout all the stages of course design:

- Identifying target situation

- Analysing target situation

- Analysing learning situation

- Writing syllabus

- Writing materials

- Teaching materials

- Evaluating learner achievement

The process is illustrated in the following diagram. 


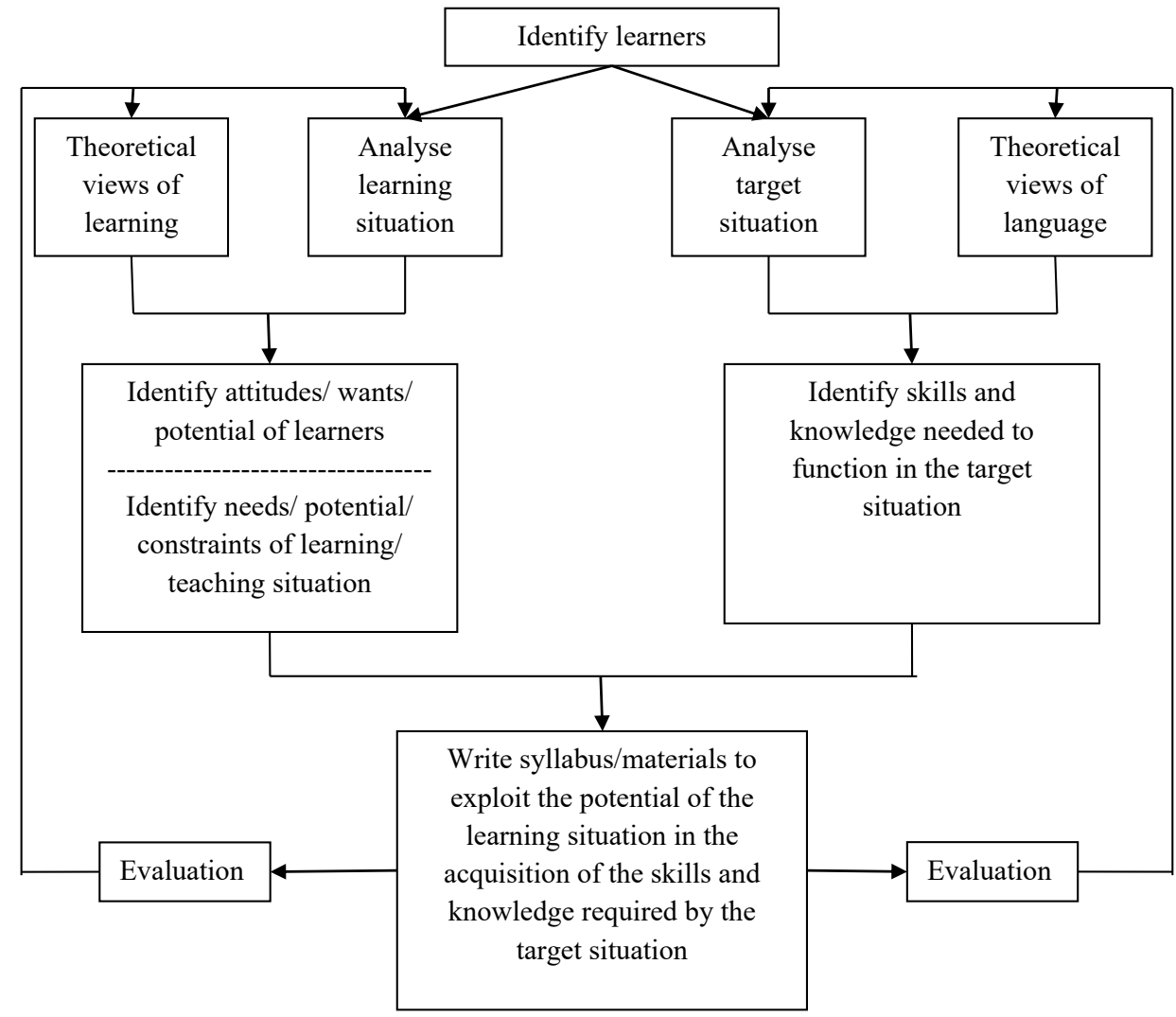

Fig. 3. Course design (Hutchinson and Waters, 1987) ${ }^{-}$

Evidently, it is of paramount importance that a number of situational, teaching and learning parameters be considered in the field of syllabus design for ESP, and by extension EAP.

\section{Needs analysis}

Given the strong link between ESP and specific learner needs, Needs analysis or Needs assessment has been an inextricable part of the ESP movement (thereby of EAP as well) since the advent of ESP, or rather emerged within the latter field. In fact, the need to specify the particular needs of learners emerged in the second half of the twentieth century and while the demand for English language learning was increasing. Since the linguistic competencies required by specific 
groups of learners (for example, professionals or military officials) regarding register and features had to be pinpointed, Needs analysis became an important part of syllabus and course design. In Europe the Council of Europe responded to the issue by proposing a framework for designing language courses for adults, while internationally the ESP movement recognised the necessity of appropriate preparation of non-native students wanting to study at British and American Universities (Richards, 2001).

In terms of literature, Munby's (1978) widely acknowledged work Communicative Syllabus Design, can be said to have marked a milestone in the history of Needs analysis with Munby's introduction of the Communication Needs Processor (CNP), a standardized procedure for identifying learners' communication needs. In defining Needs analysis, it is worth noting that even the term needs has been described in a number of ways, such as demands, motivations, goals, deficiencies, desires (Dudley-Evans \& St John, 1998). As for Needs analysis per se, it has been defined as "the first step in the course-design cycle in ESP and refers to the systematic analysis of what learners need in order to operate in the target communicative situation" (Woodrow, 2018) or as the collection and analysis of data in a systematic fashion with a view to producing a tenable curriculum (Brown, 2016).

An important aspect of Needs analysis is the type of needs that have to be identified. To that end researchers have classified needs in a number of ways. Hutchinson and Waters (1987) draw a distinction between target needs (what learners need the language for) and learning needs (what the learners have to do to learn the language). The authors proceed to distinguish between necessities (as defined by the target situation), lacks (what the learners do not know yet) and wants (which may not be the same as what teachers believe students should be taught). The latter is reminiscent of Berwick's (1989) distinction between felt needs (needs as felt by the learners) and perceived needs (the needs as felt by the teachers). A further classification distinguishes between objective needs and subjective needs (Brindley, 1989). Objective needs relate to the language students need to learn and the target situations in which the language will be used. Subjective needs, on the other hand, pertain to emotional needs, personal learning styles and expectations, and are more difficult to identify.

Frameworks for a Needs analysis process can be provided by relevant literature (Woodrow, 2018). One of them is the framework offered by BocanegraValle (2006), drawing on EAP research. Below are the stages of the Needs analysis procedure based on Bocanegra-Valle's framework: 
- Target situation analysis

- Discourse analysis

- Present situation analysis

- Learner factor analysis

- Teaching context analysis

- Task based analysis.

Lastly, following the examination of researchers' efforts to standardise and add reliability to Needs analysis procedures, another approach is also worth noting. Benesch (1996) proposes that a critical approach to Needs analysis should be adopted, arguing that Needs analysis is not an objective process, but a political and subjective one and therefore identifying the target situation cannot be free of the analyst's own beliefs and attitudes.

\section{Conclusion}

ESP and EAP are key fields in English language pedagogy and especially in Higher Education. An insight into the EAP and ESP typology is essential when designing or teaching on EAP/ ESP courses. This chapter aimed to offer a conceptual analysis of ESP and EAP and to provide a discussion on related aspects of language pedagogy; the curriculum, the syllabus, course design and needs analysis. ESP (and its branches, such as EAP) emerged out of the need for adapting teaching methodology and materials to suit specific learner needs. In order to achieve that, the analysis of a number of factors has to be taken into account, including (but not limited to) learner needs, learning context, target situation, syllabus and materials.

\section{References}

Apple, M. W. (1990). Ideology and Curriculum. New York: Routledge.

Basturkmen, H. (2010). Developing Courses in English for Specific Purposes. London: Palgrave Macmillan.

Benesch, S. (1996). Needs analysis and curriculum development in EAP: An example of a critical approach. TESOL Quarterly, 30(4), 723-738.

Berwick, R. (1989). Needs assessment in language programming: from theory to practice. In R. K. Johnson (ed.), The Second Language Curriculum, (pp. 48-62). Cambridge: Cambridge University Press.

Blaj-Ward, L. (2014). Researching Contexts, Practices and Pedagogies in English for Academic Purposes. London: Palgrave Macmillan. 


\section{Ourania Papadima}

Bocanegra-Valle, A. (2006). Needs analysis for curriculum design. In K. Hyland \& P. Shaw (eds.), The Routledge Handbook of English for academic purposes, (pp. 560-576). Oxford: Routledge.

Brindley, G. (1989). The role of needs analysis in adult ESL program design. In R. K. Johnson (ed.), The Second Language Curriculum, (pp. 63-78). Cambridge: Cambridge University

Brown, J. D. (1995). The Elements of Language Curriculum. USA: Heinle \& Heinle.

Brown, J. D. (2016). Introducing Needs Analysis and English for Specific Purposes. Oxford: Routledge.

Bruce, I. (2005). Syllabus design for general EAP writing courses: A cognitive approach. Journal of English for Academic Purposes, 4, 239-256.

Clark, J. L. (1987). Curriculum Renewal in School Foreign Language Learning. Oxford: Oxford University Press.

Crombie, W. (1988). Syllabus and Method: System or licence? System, 16(3), 281-298.

Dewey, J. (1938). Experience and Education. New York: Collier Books.

Dudley-Evans, T., \& St. John, M.-J. (1998). Developments in English for Specific Purposes. Cambridge: Cambridge University Press.

Flowerdew, J. \& Peacock, M. (2001a). Issues in E.A.P.: A Preliminary Perspective. In J. Flowerdew, \& M. Peacock (eds.), Research Perspectives on English for Academic Purposes, (pp. 8-24). Cambridge: CUP.

Flowerdew, J. \& Peacock, M. (2001b). The EAP curriculum: Issues, methods, and challenges. In J. Flowerdew \& M. Peacock (eds.), Research Perspectives on English for Academic Purposes, (pp. 177-194). Cambridge: Cambridge University Press.

Graves, K. (1996). Teachers as Course Developers. Cambridge: Cambridge University Press.

Hutchinson, T. \& Waters, A. (1987). English for Specific Purposes. Cambridge: Cambridge University Press.

Hyland, K. \& Hamp-Lyons, L. (2002). EAP: Issues and directions. Journal of English for Academic Purposes, 1, 1-12.

Hyland, K. (2006). English for Academic Purposes. An Advanced resource handbook. London: Routledge.

Johnson, K. \& Johnson, H. (1998). Encyclopedia Dictionary of Applied Linguistics. Oxford: Blackwell.

Kachru, B. B. (1985). Standards, codification and sociolinguistic realism: The English language in the outer circle. In R. Quirk \& H. Widdowson (eds.), English in the world: teaching and learning the language and literature, (pp. 11-30). Cambridge: Cambridge University Press.

Krahnke, K. (1987). Approaches to Syllabus Design for Foreign Language Teaching. New Jersey: Prentice Hall.

Lee, W. R. (1980). National Syllabuses Construction for Foreign-Language Teaching: Reconciling the Approaches. ELT documents 108, 81-85. England: The British Council.

Margolis, E. (Ed). (2001). The Hidden Curriculum in Higher Education. New York: Routledge.

McDonough, J., Shaw, C. \& Masuhara, H. (2013). Materials and Methods in ELT: A Teacher's Guide Book (2nd ed.). Oxford: Blackwell.

Munby, J. (1978). Communicative Syllabus Design. Cambridge: Cambridge University Press.

Nunan, D. (1988). The Learner-Centred Curriculum. A Study in Second Language Teaching. Cambridge: Cambridge University Press

Nunan, D. (1993). Introducing Discourse Analysis. London: Penguin.

Núñez y Bodegas, I. D. (2007). From curriculum to syllabus design: The different stages to design a programme. Memorias Del III Foro Nacional de Estudios En Lenguas. Tapachula: 
Universidad Autónoma de Chiapas. Retrieved from http://fel.uqroo.mx/adminfile/files/ memorias/Articulos_Mem_FONAEL_III/Nunez_y_Bodegas_Ir ma_Dolores.pdf

Paltridge, B. \& Starfield, S. (eds.). (2013). The Handbook of English for Specific Purposes. Boston: Wiley-Blackwell.

Popham, W. J. (2004). Curriculum, instruction, and assessment: Amiable Allies or Phony Friends? Teachers College Record, 106(3), 417-428.

Rahman, M. (2015). English for Specific Purposes (ESP): A Holistic Review. Universal Journal of Educational Research, 3(1), 24-31.

Richards, J. C. (2001). Curriculum Development in Language Teaching. Cambridge: Cambridge University Press.

Sambell, K., \& McDowell, L. (1998). The Construction of the hidden curriculum: messages and meanings in the assessment of student learning. Assessment \& Evaluation in Higher Education, 23(4), 391-402, retrieved from DOI: 10.1080/0260293980230406

Semper, J. V. O. \& Blasco, M. (2018). Revealing the hidden curriculum in higher education. Studies in Philosophy and Education, 37(5), 481-498. Retrieved from https://doi.org/10.1007/s11217018-9608-5

Strevens, P. (1988). ESP after twenty years: A re-appraisal. In M. Tickoo (ed.), ESP: State of the Art (pp. 1-13). Singapore: SEAMEO Regional Language Centre.

Swales, J. M. (1990). Genre Analysis: English in Academic and Research Settings. Cambridge: Cambridge University Press.

Thornton, S. (2014). Hidden Curriculum. In Encyclopedia of Educational Theory and Philosophy. Retrieved from http://dx.doi.org/10.4135/9781483346229.n165

Vallance, E. (1974). Hiding the hidden curriculum: An interpretation of the language of justification in nineteenth-century educational reform. Curriculum Theory Network 4(1), 5-22.

White, R. (1988). The ELT Curriculum. USA: Cambridge University Press.

Widdowson, H. G. (1990). Aspects of Language Teaching. Oxford: Oxford University Press.

Wilkins, D. (1976). Notional Syllabuses: A Taxonomy and Its Relevance to Foreign Language Curriculum Development. London: Oxford University Press.

Woodrow, L. (2018). Introducing Design in ESP. [Ebook]. New York: Routledge. 